
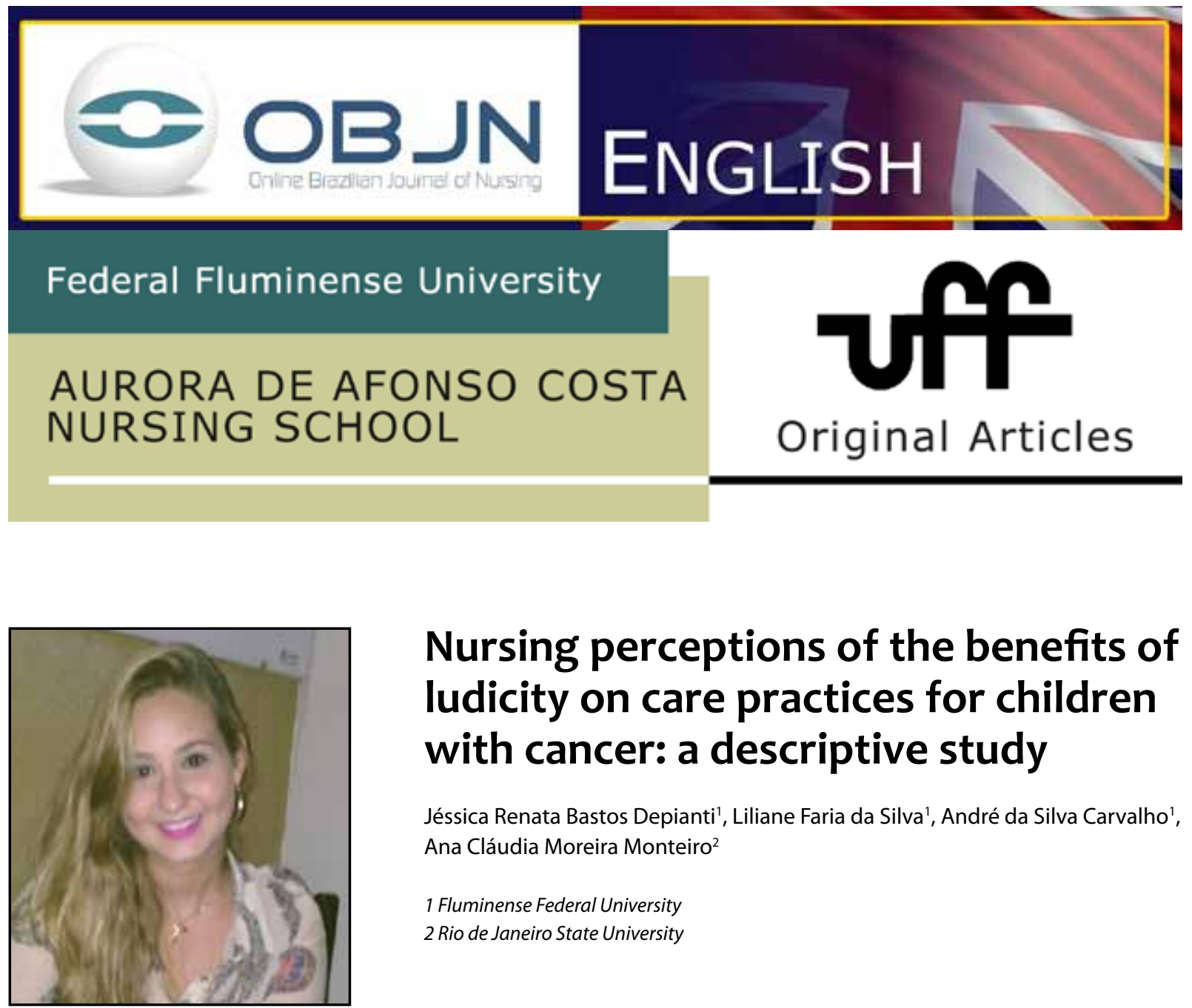

\title{
Nursing perceptions of the benefits of ludicity on care practices for children with cancer: a descriptive study
}

\author{
Jéssica Renata Bastos Depianti', Liliane Faria da Silva', André da Silva Carvalho', \\ Ana Cláudia Moreira Monteiro² \\ 1 Fluminense Federal University \\ 2 Rio de Janeiro State University
}

\begin{abstract}
Aim: To describe the benefits of using ludicity during care practices for hospitalised children with cancer, according to the perceptions of the nursing team. Method: This is a qualitative, descriptive research, carried out with the help of a nursing team in a paediatric inpatient ward for children with cancer. The collection of data was performed using non-participative observations and semi-structured interviews. The data was treated using thematic analysis. Results: The benefits of ludicity include, better adherence to treatment, improvements in relationships between the nursing team and the child, and improvements in the acceptance of caring proceedings. Discussion: According to the perception of the professionals, ludicity facilitates the process of adapting the child to hospital, and improves the relationship between the child and the nursing team. Conclusion: Ludicity brings benefits to the hospitalised child, as it helps them to adapt and provides a more qualified and humanised healthcare service.
\end{abstract}

Descriptors: Play and Playthings; Hospitalized Children; Pediatric Nursing; Neoplasms. 


\section{INTRODUCTION}

Childhood cancer is the term used to define a series of non-contagious diseases that affect children and adolescents up to the age of 19. In general, the diseases appear as modified cells that multiply rapidly and erratically in a certain organ, impairing its operation, and can spread to other organs, generating metastasis ${ }^{(1)}$. Among the many types of childhood cancer, there is a predominance of leukaemia, corresponding to $45 \%$ of all paediatric tumours, followed by lymphoma in $25 \%$ of cases. Regarding the solid tumours, the ones located in the central nervous system (CNS) are the most common, accounting for up to $22 \%$ of all neoplasms found during childhood $^{(1)}$.

Despite technological developments in the diagnosis and treatment of cancer, especially the understanding of the aetiology, the causes of childhood cancer are still unknown, which is different from the tumours found in adults, and where there is a list of risk factors related to the illness. Even though considered rare, childhood cancer represents $0.5 \%$ to $3 \%$ of all neoplasies ${ }^{(1)}$.

The diagnosis of cancer results in feelings such as anger, fear, anguish, powerlessness, helplessness, sadness, despair, and particularly the fear of death ${ }^{(2)}$. The illness generates great commotion, but fortunately, in approximately $70 \%$ of cases, when treated in specialised centres by an interdisciplinary team, progress is good, even achieving a cure ${ }^{(1)}$. In the majority of cases, this pathology requires long periods of hospitalisation, requiring the patient to adapt to a new environment for an undetermined period.

With regard to hospitalisation, prior to admission, children can experience stress, which continues during their stay and after discharge. Many children, especially those under four years old, demonstrate temporary behavioural changes after discharge. Such changes originate from the separation from close relatives and the lack of opportunities to create new bonds in a foreign environment ${ }^{(3)}$. It is important to bear in mind that children can demonstrate some irritation and stress due to hospitalisation and the pathology, and during the hospitalisation period nursing professionals require a certain sensibility to deal with the child's emotional state, as well as with the patient's relatives.

Hospitalisation is difficult for the child and can be a traumatic experience because they are away from the family environment and have to adapt to a new environment, filled with routines, equipment and different people ${ }^{(4)}$. Besides the stress of changing routine, cancer has an impact on the life of the child, because it requires a long period of treatment. During this period, games can be used to help teach children how to cope ${ }^{(5)}$.

To be a nurse in paediatric oncology, it is necessary to have an understanding of specific technical and scientific processes that are essential to the practice. Working in this area demands time and dedication, and includes ethical and emotional considerations, cognitive aspects, sensibility, understanding, and intuition ${ }^{(6)}$. Therefore, taking care of children demands that the nursing team practice a holistic and humane approach, observing how the individual who is in need of inherent care is feeling, not only due to their pathological state, but also because of their psychological and social requirements.

In this sense, the ludic can be used as an instrument to generate an effect in nursing care, because it helps to amplify the care provided beyond a purely physiopathologic observation, allowing the child to develop an expectation and understanding regarding their own hospitalisation ${ }^{(7)}$. When taking care of children, it is important that the professional is sensible and open to changes in the paediatric unit, taking into consideration the particularities of every child, their growth, and development process ${ }^{\left({ }^{(8)}\right.}$. 
In an attempt to understand the role of ludicity for children in hospital, this research was based on the conceptions of Vygotsky as a theoretical benchmark ${ }^{(9)}$. Vygotsky sees the significance of toys for all age groups and for each stage of child development, because they can become instruments for their development ${ }^{(9)}$.

Toys create an opportunity for child development and transformation through learning, by exercising imagination, which is a new psychological process for the child. It represents a specifically humane format of conscious activity, not present in very young children, and absent in animals $s^{(9)}$.

Many professionals discuss and try to conceptualise ludicity, which has a wider definition and can be interpreted through an object, or the action of playing. Other ways to express ludicity include games and ludicity, which are capable of generating feelings related to happiness, pleasure, and satisfaction. Hence, we often see the use of words such as game, toy, play, party, and ludicity substituted for the term "ludic"(10).

Vygotsky says the word toy is used more broadly, and refers mainly to an activity, the action of playing. We opted to use the words play, toy, ludicity, and game, in accordance with Vygotsky's ideas, as being a natural process for the child, without linking the words to the definitions in dictionaries. Throughout this study, these words serve as synonyms of the term ludic ${ }^{(9)}$.

The use of ludicity is capable of transforming the hospital environment, as well as generating conditions to minimise psychological damage and the psychic elaboration of daily experiences. When used in therapeutic proceedings, such as those that are invasive and cause pain, ludicity can prepare the child better than other techniques, helping them develop resilience ${ }^{(11)}$. It is also an adequate method to help confront of the whole hospitalisation process ${ }^{(12)}$.
Despite being well known in literature, the benefits of ludicity are not yet widely used in daily nursing practices for children with cancer. During discussion, there was the motivation to develop this idea, based on the following guiding question: Do the nursing team see the benefits of using ludicity when hospitalising the child with cancer?

The aim of this study is to establish the perceptions of the nursing team regarding the benefits of using ludicity when hospitalising children with cancer. The aim is to describe the benefits of using ludicity when hospitalising a child with cancer, from the point-of-view of the nursing team.

\section{METHOD}

This is a descriptive study, with a qualitative approach ${ }^{(13)}$, performed in the paediatric unit of a public hospital, located in the Brazilian state of Rio de Janeiro, responsible for supporting children with cancer. The subjects of this research were 11 professionals from the nursing team, consisting of four nurses and seven nursing technicians, who work in the paediatric unit chosen by this study.

The option to work with these two types of professionals was defined by the fact they are in direct contact with children during hospitalisation, and because they provide the nursing care. The criteria to include the subjects were, professionals working for at least one year in the area of study and professionals who directly care for the children affected. The criteria for exclusion of subjects were professionals on medical leave and/or on vacation.

The number of subjects was established during field observation, when, based on the organisation of the testimonies, it was possible to identify the "moment of data saturation", or 
in other words, the existence of a repetition of ideas, behaviour patterns, practices and visions of the world ${ }^{(14)}$.

The data collection was performed in two stages. The first stage was by non-participative observation, performed over five days, during the morning shift for five consecutive hours - a total of 25 hours of observation. An observation guideline was used, which was composed of questions related to the physical structure of the unit, such as the colour of walls, the presence, or lack of a child-friendly atmosphere and toys. The approach used towards the child by the nursing team during regular proceedings was also observed. During this period of nonparticipating observation, it was possible to identify the physical characteristics of the unit and the working dynamics of the nursing team.

The second stage of this research was composed using a semi-structured interview consisting of open-ended and closed questions. For a full and precise record of the testimonies of the subjects, the interviews were recorded using an MP3 voice recorder, and with authorisation from the subjects, who signed the Free and Clear Consent Agreement (FCCA). To guarantee the anonymity of the subjects, they were identified by the names of games. The data collection started after the approval of this research project by the Committee of Ethics and Research of the hospital in which it took place (protocol \#275/11).

The data originating from the transcription of the testimonies was treated by thematic analysis, following the stages described in the analytic method; superficial reading, exploitation of the material, treatment, and interpretation of the results ${ }^{(14)}$.

After transcription of the interviews, the material was analysed and the testimonies were classified using a colourimetric method, or in other words, the text was coloured according to repetitions of meaningful words and expressions. Then the data was aggregated, which generated the specificity of the thematic units.

\section{RESULTS}

The benefits of using ludicity for the child

The people who have direct contact with the child highlighted some of the benefits of using ludicity to assist children:

\begin{abstract}
They understand what has to be done, they understand it and accept the procedure better (Scattergories).
\end{abstract}

It makes the child trust us. They trust us because of the toys (Hopscotch).

Children accept the treatment better, sometimes using storytelling, creating a story based on the procedure you are about to perform (...) they understand it better than if you simply come up and impose the treatment (Dodge Ball).

They adapt better to the environment, alleviating the pain, and they feel more comfortable (...) it makes them think you are a friend and that you like the child (Riddle).

As the subjects expressed, the ludicity demonstrated in toys and storytelling is an instrument that can help in the care of children hospitalised with cancer, as it works to improve how they adapt to and accept the proceedings. In addition, it alleviates pain, increases understanding regarding treatment, and helps strengthen the bond between child and professional, as it increases the trust between them and the 
relatives with those on the team managing the caring procedures.

The benefits of the use of ludicity on the social interactions of the child

There were benefits on the interactions between the child, the mother, and the nursing team. It was mentioned that ludicity facilitates nursing care to the child with cancer, thus optimising work routines.

The use of ludicity optimises work routines (...) because it improves the collaboration of the child and the participation of the mother (...); it creates a higher involvement between the nursing team, the mother that is accompanying the child, and the child himself (Hide-and-seek).

I think it is important to get the child on our side, because the world of the child is full of fantasies (...), telling stories is an easy way to bring the child with us and facilitate our work routines (Blind Man's Bluff).

The benefit works for both the child, and us because it is terrible to treat a child with leukaemia, as they are moody when in pain, therefore it is easier for us to get closer to the patient (Catch-me-if-you-can).

Despite the improvements in adapting the child into the hospital environment, the ludicity was also said to facilitate in the social interaction of the child with the nursing team, and with the accompanying mother. Through ludicity, the professionals find alternatives to approach the child, such as storytelling, and then find they are able to collaborate with the patient and the mother, and consequently this helps work routines.

\section{DISCUSSION}

Among the benefits of using ludicity on the child, the professionals drew attention to the fact it facilitates understanding and generates acceptance of the treatment procedures. This data corroborates a study where it is demonstrated that when playing, children learn to deal with and control their realities ${ }^{(9)}$, as well as it helping to create an environment of acceptance and fulfilment of nursing care ${ }^{(12)}$. Another important aspect highlighted by the subjects is the use of storytelling as a ludic resource. It is possible to affirm that the child, through handling objects and being involved in stories, has a better understanding of their hospitalised situation, which makes the procedures less stressful for them ${ }^{(15)}$.

With regard to the involvement of the child through stories, it is important to mention that this type of strategy facilitates the role game, also known as the make-believe game, in which the child is capable of symbolically representing his experience ${ }^{(9)}$, which helps them express and confront the situation causing discomfort.

The trust established by using ludicity was also mentioned in the testimonies of the subjects. A recent study demonstrates that the use of this resource strengthens the bond between the child and the nursing team, permitting a better interaction between caregiver and the person who is cared for ${ }^{(12)}$. It enables the creation of an effective and indispensable communication link during the process of caring, permitting the identification of the needs of the child, and preparation for the procedures the patient will go through, increasing the bonds of trust between both ${ }^{(16)}$. 
Another important issue is the best adaptation procedure for the child in the hospital environment. Professionals show that ludicity helps in caring for the hospitalised child with cancer, by assisting their adaptation and acceptance of procedures. This aspect needs attention, because, from the point-of-view of the child with cancer, the hospital environment can represent a place of physical and emotional suffering, where they are forced to deal with the unknown. Such scenarios can generate fear, irritation, despair, anxiety, guilt, depression, and tearfulness ${ }^{(17)}$.

The professionals also said that playing could alleviate the physical symptoms of cancer treatment. Pain was mentioned in a study ${ }^{(18)}$ as one of the main preoccupations of children, because cancer is known as a painful disease, physically, emotionally and spiritually. Despite alleviating the physical symptoms, ludicity works to reduce stress caused both by hospitalisation and treatment, such as the antineoplasic chemotherapy $^{(19)}$.

In this context, it is important to use tools to help children with cancer to confront the process of treatment and hospitalisation ${ }^{(17)}$. While playing, they feel happier and forget the illness, and easily adhere to drug therapy, as the priority of ludicity is in the pleasure of the child ${ }^{(20)}$.

The subjects also showed that when they use creativity and ludicity during the care of children with cancer, they see a higher collaboration on the part of the patient and the accompanying mother, allowing the care to be performed more effectively. This data corroborates a study ${ }^{(12)}$ that demonstrates playing as a facilitator of the interaction between health professionals, the children, and the relatives, because the games create an environment of affection and emotion. Despite that, the ludicity amplifies the perception of care beyond a purely physiological body, as it involves the manifestations of affection towards the child, and permits an understanding of the subject as a whole, not only of the illness that afflicts the patient ${ }^{(9)}$.

It is necessary for the nursing team to know the benefits of ludicity and apply it during the care of the hospitalised child with cancer, to improve the quality of care ${ }^{(16)}$. The nurse has a fundamental role in the care of these patients, as they work directly with them to improve their quality of life ${ }^{(7)}$.

Some studies ${ }^{(15-20)}$ demonstrate the different benefits of the use of ludicity, and it is important to mention that during the collection of data there were few moments using this resource. For example, during the verification of vital signs, where the nursing team interacted with the child while the child was handling toys, they approached the child using simple language.

With a bit of creativity, it is possible to create different resources and strategies for play, such as the use of clothing and accessories with children's motifs, puppets, and telling stories during proceedings, and playing music. Using these resources helps strengthen bonds and there are positive results for the hospitalised child with cancer, the relatives, and the professional team.

\section{CONCLUSION}

Hospitalisation causes changes to the routine of children and their families, and they have to adapt to their new reality. This generates distance between other relatives, colleagues and their usual routine. In the child, it causes behavioural and emotional changes, making them feel insecure, anxious, and fearful in the new environment. 
In this context, we conclude that the use of ludicity in the care of the child with cancer helps the process of adaptation to the hospital environment, mediating the bond between the professional, the child, and the family, and reducing stressful factors that can harm the patient.

Despite publications about the success of ludicity for the hospitalised child with cancer, the reality is very different to that in the articles. As was observed, even among the nursing professionals who know about the benefits of ludicity, they rarely use it as a resource during care procedures.

It is necessary to advance the practice to include more humanised and individualised care, preconizing not only changing routine procedures, but also taking into consideration the singularity and imagination of each child. The nursing team are also required to implement the ludicity in their daily practice, using it during evaluation, diagnosis, and nursing interventions.

\section{REFERENCES}

1. Instituto Nacional do Câncer (BRASIL). Ações de enfermagem para o controle do câncer: uma proposta de integração e serviço. Instituto Nacional do Câncer. - $3^{a}$ ed. rev. atual. ampl. Rio de Janeiro: INCA; 2008.

2. Salci MA, Marcon SS. A convivência com o fantasma do câncer. Rev Gaúcha Enferm., Porto Alegre (RS) 2010 mar;31(1):18-5.

3. Hockenberry MJ, Wilson D, Winkelstein ML. Wong fundamentos da enfermagem pediátrica. 8. ed. Rio de Janeiro: Elsevier, 2011.

4. Silva LF, Cabral IE, Christoffel MM. The (im) possibilities of play for children with outpatient cancer treatment. Acta Paul Enferm. 2010; 23(3): 334-40.

5. Nascimento LC, Oliveira FCS; Moreno MF; Silva FM. Cuidado espiritual: componente essencial da prática da enfermeira pediátrica na oncologia. Acta Paulista Enfermagem 2010; 23(3):437-40.

6. Mendes LR, Broca PV, Ferreira MdeA. A leitura mediada como estratégia de cuidado lúdico: contribuição ao campo da enfermagem fundamental. Esc. Anna Nery Rev Enferm. 2009, jul-set; 13 (3): 530-36

7. Gomes ILV, Queiroz MVO, Bezerra LLdeA, Souza NPG. A hospitalização no olhar de crianças e adolescentes. Cogitare Enferm. 2012 out/dez; 17(4):703-09.

8. Leon PAP, Nobrega MML. Diagnóstico de enfermagem em crianças hospitalizadas utilizando a NANDA-I: estudo de caso. Online braz j nurs [Internet]. 2012 [Citado em 23 fev 2013] 11 (1). Disponível em: http://www.objnursing.uff.br/index.php/nursing/article/view/3553. doi: http:// dx.doi.org/10.5935/1676-4285.20120007

9. Vygotsky LS. A formação social da mente: o desenvolvimento dos processos psicológicos superiores. 7a ed. São Paulo: Martins Fontes; 2007.

10. Beuter M, Alvim NAT. Expressões lúdicas no cuidado hospitalar sob a ótica de enfermeiras. Esc. Anna Nery Rio de Janeiro, 2010. jul/set; 14(3)3.

11. Cruz DSM, Collet N, Marques DKA. Importance of using therapeutic toys in care of children with diabetes type 1. J Nurs UFPE on line. 2012, apr; 6(4):858-62

12. Maia EBS, Ribeiro CA, Borba RIH. Compreendendo a sensibilização do enfermeiro para o uso do brinquedo terapêutico na prática assistencial à criança. Rev Esc Enferm. USP, 2011; 45(4):839-46

13. Minayo MCS. Los conceptos estructurantes de la investigación. Salud Coletiva. 2010; 6(3): 251-61.

14. Fontanella BJB, Luchesi BM, Saidel MGB, Ricas J, Turato ER, Melo DM. Amostragem em pesquisas qualitativas: proposta de procedimentos para constatar saturação teórica. Cad. Saúde Pública. 2011; 27(2): 389-94.

15. Marileno GS, Santos G, Pereira D. Estratégias lúdicas na assistência ao paciente pediátrico: aplicabilidade ao ambiente cirúrgico. Rev. SOBECC São Paulo, 2013; abr/jun; 18(2): 57-66. 
16. Cruz DSM, Virgínio NA, Maia FSB, Martins DL, deOliveira AMS. Brinquedo terapéutico: revisão integrativa. Rev enferm. UFPE on line. 2013, mai; 7(5):1443-48.

17. Dias JJ, Silva APC, Freire RLS, Andrade ASA. Experience of children with cancer and the importance of recreational activities during hospitalization. Rev Min Enferm. 2013, jul/set; 17(3): 614-19.

18. Pontes CM, Kurashima AY. Criança com câncer: revisão de literatura sobre sinais e sintomas presentes na fase de cuidados paliativos. Rev Soc Bras Enferm Pediatr. 2009; 9(1):27-31.

19. Artilheiro APS, Almeida FA, Chacon JMF. Use of therapeutic play in preparing preschool children for outpatient chemotherapy.Actapaul. enferm. [Internet]. 2011 [cited 2014 marc 04]; 24(5):611-616. Availble from: http://www.scielo.br/pdf/ape/v24n5/en_03v24n5.pdf

20. Silva D F, Corrêa I. Reflexão sobre as vantagens, desvantagens e dificuldades do brincar no ambiente hospitalar. Rev Min Enferm. 2010; 14(1):37-42.
All authors participated in the phases of this publication in one or more of the following steps, in According to the recommendations of the International Committee of Medical Journal Editors (ICMJE, 2013): (a) substantial involvement in the planning or preparation of the manuscript or in the collection, analysis or interpretation of data; (b) preparation of the manuscript or conducting critical revision of intellectual content; (c) approval of the versión submitted of this manuscript. All authors declare for the appropriate purposes that the responsibilities related to all aspects of the manuscript submitted to OBJN are yours. They ensure that issues related to the accuracy or integrity of any part of the article were properly investigated and resolved. Therefore, they exempt the OBJN of any participation whatsoever in any imbroglios concerning the content under consideration. All authors declare that they have no conflict of interest of financial or personal nature concerning this manuscript which may influence the writing and/or interpretation of the findings. This statement has been digitally signed by all authors as recommended by the ICMJE, whose model is available in http://www. objnursing.uff.br/normas/DUDE_eng_13-06-2013.pdf

Received: 03/16/2013

Revised: 04/01/2014

Approved: 04/15/2014 